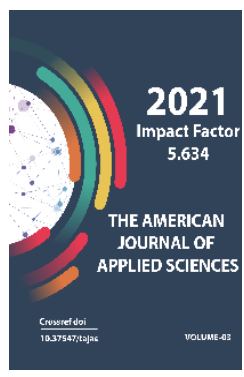

\title{
Khorezm Dutor Moments
}

\author{
Shodmonova Durdona \\ Stage 4 Student, Department Of "Maqom Singer"Named After Yunus Rajabi " Uzbek \\ National Music Art Institute, Uzbekistan
}

Journal Website:

http://usajournalshub.c

om/index,php/tajas

Copyright: Original

content from this work

may be used under the

terms of the creative

commons attributes

4.0 licence.

\section{ABSTRACT}

Issues related to the classical samples of Uzbek classical music heritage occupy one of the leading places in the modern music culture. In this regard, among the Bukhara Shashmakomi, FerganaTashkent status roads, Khorezm status categories, Dutor status, in our opinion, are of great interest. In particular, the study of the generality and differences in the interpretation of their old rare and diverse new performance, in full case or in the recording of parts into a note, is of paramount importance.

This article is about the status of Khorezm

\section{KEYWORDS}

Status, Khorezm, dutor status, shashmakom, Peacock of dutor status, instrumental ways.

\section{INTRODUCTION}

The status was considered "Palace music" from time immemorial. In order to understand deep philosophy in the status of Uzbek classical music, which is required to have a high level of the worldview, musical knowledge and potential of the listener, "Buxoro shashmakomi”, "Khorezm status”, "FerganaTashkent status roads", "Wild status", “" 
Surnay and Dutor status roads " have emerged. Over the centuries, these masterpieces of heritage have been delivered to us as far as possible. As long as it has reached our era, in the direct transition of the musical heritage from the master to the shogird, the tabarruk beings, together with the transition of the bridge function, have also been able to sing with their own performances. When we say the status of Dutor, on the one hand, classical music, on the other hand, the so-called folk tunes, are understood as acting whole-headed works. Later, a new generation of musicians turned to this topic, collecting information on the meaning and development of Dutor's status, a little silenced the promotion of Dutor's status.

Khorezm is one of the oldest cultural centers, and the peoples of Central Asia have played a decisive role in many aspects in the history of development. Speaking about the status in the teacher's conversations, there were opinions that for the first time our status was improved by scientists from the Makhmun Academy. Because at that time, teachers who did not pass the exam from the theory of music at the Academy of Management said that the scientist was not given a degree of maturity. This is due to the assumption that from that time on, scientists began to write treatises on music.. Statuses are one of the famous monuments of Khorezm music. Khorezm status also came into existence many centuries ago, like the Bukhoro shashmakoms, and has been preserved so far on the basis of folk tradition.

Matyusuf Harratov (1881-1953), one of the famous Khorezm musicians, stated in his book "Khorezm musical history" that the creation of Khorezm status was directly associated with
Bukhara shashmakomi. He said that " Khivalik musikunos Niyazjon Hodja will go to Bukhara to study his classical propaganda in the performance of tanbur in our music. The origin begins to teach the iqtidor shogirds in tanbur"" Because before that, in the status of Khorezm, dutor was the leader. Since the beginning of the XIX century in the status of Khorezm, tanbur Suz began to lead.

Dutor status is one of the most ancient terms in the com system. To be more precise, it is a mythical concept that has been well-united and is now coming back into musical infancy. Two parts of this word combination - "dutor" and "maqom" are phraseological units of the word olam-olam.

The first written makhlumat about the status of Dutor is "Khorezm musical history" (Moscow, 1925. In the Uzbek language, the Arabic alphabet). "In Khorezm, before the Mongol invasion, dutor was one of the most famous and most used musical instruments, " he said in the game. Just before the invasion of Genghis Khan there are specimens that say that in a blindfold the number of those who sell Harras to dutore reaches a thousand.

It is possible to know that the dutor Sazi was popular among the general Turkish Saz in Khorezm from a very ancient time when it was more common among the people than tanbur. But it is not arranged lazily. Mullo Mohamed SHarif, nicknamed" grandfather", made a rather sexy move, thinking about transferring the nags of dutor to a special line. However, due to the difficulty in clicking and the narration of the slices, the dutor nags were not transferred to the paper, as the narration ceased in the past times. 
The letter of Dutor, one of the roots of the musical heritage of Khorezm, has become the noble intention of the fidai artist to draw the attention of generations to the order and order of this noble heritage as perfectly as possible. Zaki artist Kamil Devoniy, who successfully mastered the status system, chose a different way in this work than the previous Masters. It turned out that all the components of the Dutor statuses were written in the style of the circle method, the text of the word and the General History of sentences according to them in a solo.

The first period of the development of the dutor instrument can be attributed to the periods of liberation of the blindfold. During this period, dutor was able to make a lot of progress. We can show the famous Yusufbek from the dutorists who reached this period.

The second period is Said Muhammadhan and Muhammed Rahimkhon's second period, during which the previous state of the dutar Saz changed. The value of the dutor instrument has increased. Among such instruments as tanbur, fiddle, sledgehammer, circle, dutor sozi took the first place during the singing sessions of the choir and the tambourine, Beck and Beck.

For this reason, local mohir dutorists began to grow. Shular in the sentence Khivalik khujanazar the Uzbek dutorist named Kurd was a classical dutorist of his time. Such a person as khazaraspian Pahlavonboy from this Khujanazar Wolf and grandfather Miton from Khazarasp's Mitonmavze fenced off dutarism. Usmonjon and Jacob dutorists received training from grandfather Miton.

It is known that the center of the Khorezm Oasis is distinguished by its unique cultural and spiritual values in Asia. Famous artists, especially composers, honanda and musicians, who were born and worked creatively here, were also famous in the regions of the far-near Army from ancient times.

It is necessary to recognize that the status of Dutor and Tanbur was decided as an independent genre of music, which arose from various social needs. There are scientific studies on the internal structure of shashmakom and monand Khorezm Tanbur statuses, the basis of lad, rhythm, and form. A.Fitret, I.In the books of such status scientists as Rajabov, valuable information about these issues is presented.

According to the scientific description in"Khorezm music history": "although Dutor sozi is known among the people of Khorezm country in the form of tanbur estikmach, tanbur was not disciplined in order until. Although the dutor nags were as much as the tanbur nags, they could not give the importance given to the tanbur to the dutor nags. Because the click is harder than the tap than the tap. Until na Sayidmuhammadhon and Muhammad Rahimkhon in particular Mullo Muhamad Sharif mulla Qabar Baba Qanbardek dutorists thought to make a special line of Nag'malirini from the hand situation and sometimes nag'malarini paused from the click of the same number and zeal of those who were thinking of making a special line of Nag'malirini tavvaquf in times and some nashms quickly and quietly transfer the Nag'malarini to paper the O's SA and the additions were left empty."

Proceeding from this, we can say that getting the status of dutor into a special line has brought a lot of complexity, although it is 
difficult to please the classical music of Khorezm without a dutor instrument. In this regard, the author of the monograph "Maqomot" Atanazar Matyokubov, who conducted historical and theoretical studies on several Khorezm statuses, commented on the issue as follows: "the mention of tanbur as a leading Saz is not just a superficial discourse, but rather a concept that represents a turn in the history of Khorezm statuses. Their predecessors were the chief instrument of classical music of Khorezm and the "key" dutor. And with the penetration of the principles of shashmakom, tanbur comes out into the field. In Khorezm, the division of categories into tanbur anddutor status also starts from this point."

Thus, the status of Khorezm Dutor has been living as one of the most beautiful and lifegiving examples of the ancient and Navkiran art of this oasis.

\section{REFERENCES}

1. Mullah Bekjon Rahman Oglu, Muhammad Yusuf Devonzoda "Khorezm musical history" Tashkent, 2006.

2. Rustam Baltaev. Dotar highlights. Tashkent, 2006.

3. Matyakubov 0 . The makomat. Tashkent, 2004. 